\title{
'Flexispira rappini' strains represent at least 10 Helicobacter taxa
}

\author{
F. E. Dewhirst, ${ }^{1}$ J. G. Fox ${ }^{2}$ E. N. Mendes, ${ }^{3}$ B. J. Paster, ${ }^{1}$ C. E. Gates, ${ }^{4}$ \\ C. A. Kirkbride ${ }^{4}$ and K. A. Eaton ${ }^{5}$
}

Author for correspondence: F. E. Dewhirst. Tel : +1 6172625200 ext. 298. Fax: +1 6172624021. e-mail: fdewhirst@forsyth.org

\footnotetext{
1 Department of Molecular Genetics, The Forsyth Institute, 140 Fenway, Boston, MA 02115, USA

2 Division of Comparative Medicine, Massachusetts Institute of Technology, Cambridge, MA 02319, USA

3 Division of Laboratory Medicine/PRO, Faculdade de Medicina/UFMG, Belo Horizonte, MG, 30130-100, Brazil

4 Department of Veterinary Science, South Dakota State University, Brookings, SD 57007, USA

5 Department of Veterinary Biosciences, Ohio State University, Columbus, $\mathrm{OH} 43210$, USA
}

\begin{abstract}
'Flexispira rappini' is a provisional name given to Gram-negative, microaerophilic, motile, spindle-shaped micro-organisms with spiral periplasmic fibres and bipolar tufts of sheathed flagella. Several investigators, including Kirkbride, Romero, and Archer isolated strains possessing this morphology. Previously, the phylogenetic position of three 'Flexispira rappini' strains was determined by $16 \mathrm{~S}$ rRNA sequencing, which indicated that flexispira were members of the genus Helicobacter. As more organisms with ' $F$. rappini' morphology were isolated, it became apparent that there were multiple Helicobacter taxa with this distinctive morphology. The purpose of this study was to examine a collection of 36 ' $F$. rappini' strains from diverse habitats by using 165 rRNA sequence analysis. The strains fell into 10 taxa, each possibly representing a novel Helicobacter species. Two of these flexispira taxa were previously named, by us, Helicobacter bilis and Helicobacter trogontum. Currently, none of the flexispira taxa contains enough phenotypically and genotypically characterized strains to be formally named 'Helicobacter rappinii'.
\end{abstract}

Keywords: Helicobacter, 'Flexispira rappini', rRNA, phylogeny

\section{INTRODUCTION}

'Flexispira rappini' is a provisional name given by Bryner to Gram-negative, microaerophilic, motile, fusiform-shaped organisms with spiral periplasmic fibres and bipolar tufts of sheathed flagella (Bryner et al., 1986, 1987). Throughout this paper, the term 'flexispira' will be used to refer to organisms with this distinct morphology. A flexispira strain was first isolated in pure culture, by Kirkbride, from aborted lambs with focal hepatic necrosis (Kirkbride et al., 1985). Kirkbride was able to produce abortions in pregnant sheep by inoculating the cultured organism (strain 84-3345), fulfilling Koch's postulates (Kirkbride et al., 1986). Bryner demonstrated that the same strain could produce experimental infection, abortion in pregnant guinea pigs and hepatic necrosis in aborted feti (Bryner et al., 1987). Flexispira organisms were recovered from stool specimens from two humans, one with and one without gastroenteritis, and from their

Abbreviation: IVS, intervening sequence. asymptomatic dog, as well as from a second patient with diarrhoea (Romero et al., 1988; Archer et al., 1988). Organisms with the flexispira morphology (distinctive periplasmic fibres that have a criss-cross appearance in negatively stained electron micrographs and multiple bipolar sheathed flagella) had been previously described by Lockard as one of three morphotypes seen in the gastric mucosa of dogs (Lockard $\&$ Boler, 1970), and by Savage as one of two morphotypes in the murine large bowel (Savage et al., 1971).

The phylogenetic position of 'Flexispira rappini' strains was shown to be closely related to the genus Helicobacter by DNA-rRNA hybridization (Vandamme et al., 1991) and actually fell within the genus Helicobacter according to $16 \mathrm{~S}$ rRNA sequence analysis (Paster et al., 1991). Ongoing 16S rRNA sequencing efforts in our laboratory have indicated that ' $F$. rappini' strains represent multiple Helicobacter taxa. The purpose of the present study was to examine a large number of ' $F$. rappini' strains to determine their phylogenetic diversity and to place the strains in coherent taxa. 
Table 1. Flexispira strains

The leftmost column subheadings are strain group, followed by proposed name. The following abbreviations are used: ATCC, American Type Culture Collection; NADC, National Animal Disease Center. Strains in bold were sequenced; other numbers are alternative designations for the same strain. 'Same' indicates that the sequence is the same (within 2 base differences) as that of the GenBank number above.

\begin{tabular}{|c|c|c|c|c|c|c|}
\hline \multicolumn{3}{|c|}{ Collection accession nos } & \multirow{2}{*}{$\begin{array}{c}\text { Sequence } \\
\text { accession } \\
\text { no. }\end{array}$} & \multirow[t]{2}{*}{ Isolated by : } & \multirow[t]{2}{*}{ Source } & \multirow[t]{2}{*}{ Reference } \\
\hline ATCC & NADC & $\begin{array}{c}\text { Original } \\
\text { designation }\end{array}$ & & & & \\
\hline \multicolumn{7}{|c|}{ Flexispira taxon 1} \\
\hline 43968 & 2010 & $86-13625$ & U96300 & C. E. Gates & Pig & Archer et al. (1988) \\
\hline \multicolumn{7}{|c|}{ Flexispira taxon 2} \\
\hline \multirow[t]{2}{*}{49314} & 2012 & $86-2279$ & AF225546 & C. E. Gates & Sheep & \\
\hline & & $87-3845$ & Same & C. E. Gates & Sheep & \\
\hline 49315 & 2013 & $87-161$ & Same & C. E. Gates & Aborted sheep foetus & \\
\hline 49316 & 2015 & $87-14409$ & Same & C. E. Gates & Aborted sheep foetus & \\
\hline \multirow{2}{*}{49319} & 2039 & $88-924$ & Same & C. E. Gates & Aborted sheep foetus & \\
\hline & & $89-4925$ & Same & C. E. Gates & Sheep & \\
\hline \multicolumn{7}{|c|}{ Flexispira taxon 3} \\
\hline 49320 & 2040 & $88-2491$ & AF225547 & C. E. Gates & $\begin{array}{l}\text { Pig stomach; } \\
\text { aborted foetus }\end{array}$ & \\
\hline \multicolumn{6}{|c|}{ Flexispira taxon 4} & \\
\hline \multicolumn{7}{|c|}{ Flexispira taxon 5} \\
\hline 43966/49313 & $1893 / 2011$ & 84-3345 & M88137 & C. A. Kirkbride & Aborted sheep foetus & $\begin{array}{l}\text { Kirkbride } \text { et al. }(1985,1986) \\
\text { Bryner } \text { et al. (1987) }\end{array}$ \\
\hline \multicolumn{7}{|c|}{ Flexispira taxon 6: Helicobacter trogontum } \\
\hline \multirow{3}{*}{\multicolumn{2}{|c|}{$700114^{\mathrm{T}}$}} & $\mathbf{8 5 8 1}^{\mathrm{T}}$ & U65103 & E. N. Mendes & Rat & Mendes et al. (1996) \\
\hline & & 8718 & Same & E. N. Mendes & Rat & Mendes et al. (1996) \\
\hline & & 9056 & Same & E. N. Mendes & Rat & Mendes et al. (1996) \\
\hline \multicolumn{7}{|l|}{ Flexispira taxon 7} \\
\hline & & 1302/Dog-4 & U51874 & K. A. Eaton & Dog stomach & Eaton et al. (1996) \\
\hline \multicolumn{7}{|c|}{ Flexispira taxon 8} \\
\hline 43879 & 1937 & 38264 & M88138 & J. R. Archer & $\begin{array}{l}\text { Human stool } \\
\text { (Case } 1 \text { father) }\end{array}$ & Romero et al. (1988) \\
\hline 49308 & 1938 & 39051 & Same & J. R. Archer & Dog stool (Case 1 pet) & Romero et al. (1988) \\
\hline 49309 & 1939 & 39801 & Same & J. R. Archer & $\begin{array}{l}\text { Human stool } \\
\text { (Case } 1 \text { daughter) }\end{array}$ & Romero et al. (1988) \\
\hline 43880 & 2005 & 14020 & AF225549 & J. R. Archer & Human stool (Case 2) & Romero et al. (1988) \\
\hline \multirow[t]{7}{*}{49317} & 2016 & $87-4654$ & AF047851 & C. E. Gates & Dog stool & \\
\hline & & $87-4551$ & Same & C. E. Gates & Dog stool & \\
\hline & & $87-5733$ & Same & C. E. Gates & Dog stool & \\
\hline & & Fr-mo* & L12765 & D. S. Schauer & Mouse & Schauer et al. (1993) \\
\hline & & H3153* & AF118017 & P. Sorlin & Human blood & Sorlin et al. (1999) \\
\hline & & FH 9702248* & AF034135 & W. Tee & Human blood & Tee et al. (1998) \\
\hline & & NIH-1* & AF118807 & V. J. Gill & Human blood & Weir et al. (1999) \\
\hline \multicolumn{7}{|c|}{ Flexispira taxon 9: Helicobacter bilis } \\
\hline 51630 & & 93-1909/Hb1 & U18766 & J. G. Fox & Mouse faeces & Fox et al. (1995) \\
\hline 51631 & & 93-1920/Hb2 & U18767 & J. G. Fox & Mouse faeces & Fox et al. (1995) \\
\hline \multirow[t]{12}{*}{51632} & & $93-1990 / \mathrm{Hb3}$ & U18768 & J. G. Fox & Mouse faeces & Fox et al. (1995) \\
\hline & & 1502/Dog-5 & U51873 & K. A. Eaton & Dog faeces & Eaton et al. (1996) \\
\hline & & $96-5983$ & & J. G. Fox & Gerbil faeces & \\
\hline & & 96-6119 & & J. G. Fox & Gerbil faeces & \\
\hline & & $97-1034$ & & J. G. Fox & Hamster faeces & \\
\hline & & 9615-IN3-1 & & J. G. Fox & Rat faeces & Haines et al. (1998) \\
\hline & & 9615-IN3-2 & & J. G. Fox & Rat faeces & Haines et al. (1998) \\
\hline & & 9615-IN3-3 & & J. G. Fox & Rat faeces & Haines et al. (1998) \\
\hline & & 9615-IN3-4 & & J. G. Fox & Rat faeces & Haines et al. (1998) \\
\hline & & $92-7660 \dagger$ & AF0478431 & J. G. Fox & Human gall-bladder & Fox et al. (1998) \\
\hline & & $93-3055 \dagger$ & AF047844 & J. G. Fox & Human gall-bladder & Fox et al. (1998) \\
\hline & & $93-4659 \dagger$ & AF047845 & J. G. Fox & Human gall-bladder & Fox et al. (1998) \\
\hline Flexispira taxon & & & & & & \\
\hline & & 97-6194-5 & AF107494 & J. G. Fox & $\begin{array}{l}\text { Cotton-top tamarin } \\
\text { faeces }\end{array}$ & Saunders et al. (1999) \\
\hline & & $97-6194-4$ & Same & J. G. Fox & $\begin{array}{l}\text { Cotton-top tamarin } \\
\text { faeces }\end{array}$ & Saunders et al. (1999) \\
\hline & & $97-6194-3$ & Same & J. G. Fox & $\begin{array}{l}\text { Cotton-top tamarin } \\
\text { faeces }\end{array}$ & Saunders et al. (1999) \\
\hline
\end{tabular}

* Strain not part of this study; see reference.

$\uparrow$ PCR product, not isolate. 


\section{METHODS}

Bacterial isolation and culture. The strains examined in this report were supplied by a number of investigators, as indicated in Table 1.

Phenotypic characterization. Most of the tests were performed as previously described (Paster et al., 1991). Tests for $\gamma$-glutamyl arylamidase, phosphatase, urease and nitrate reduction were performed using the RapID/NH System (Innovative Diagnostic Systems). Indoxyl acetate hydrolysis was performed using indoxyl acetate discs (Remel).

Crude DNA isolation and amplification. Bacteria were cultured on TSA blood agar plates for $48 \mathrm{~h}$ under microaerophilic conditions. A small loopful of cells $(5 \mu \mathrm{l})$ was harvested and lysed by suspension in $15 \mu \mathrm{l}$ Gene Releaser according to the manufacturer's (BioVentures) microwave protocol. PCRs were performed in thin-walled tubes with a Perkin-Elmer 480 thermal cycler, a GeneAmp PCR reagent kit and an AmpliWax PCR Gem 100s (Promega). Forward primers C71 (Escherichia coli position 7-23; 5'-GAG AGT TTG ATC MTG GC-3') and reverse primer C72 (15091492; 5'-GYT ACC TTG TTA CGA CTT-3') were used (Fox et al., 1995). The Gene Releaser mixture was centrifuged at $14000 \mathrm{~g}$ for $2 \mathrm{~min}$. One microlitre of the clear supernatant was combined with $1 \mu \mathrm{M}$ each primer and other reagents in the Hot Start protocol suggested by PerkinElmer. The following conditions were used for amplification: denaturation at $72{ }^{\circ} \mathrm{C}$ for $45 \mathrm{~s}$, annealing at $50{ }^{\circ} \mathrm{C}$ for $45 \mathrm{~s}$ and elongation at $72^{\circ} \mathrm{C}$ for $45 \mathrm{~s}$, with $5 \mathrm{~s}$ added for each elongation step. A total of 30 cycles were performed, followed by a final elongation step at $72{ }^{\circ} \mathrm{C}$ for $15 \mathrm{~min}$. The purity of the product was determined by electrophoresis in a $1 \%$ agarose gel. DNA was stained with ethidium bromide and viewed under long-wavelength UV light.

Purification of PCR products. Amplified DNA was purified by precipitation with PEG 8000 (Kusukawa et al., 1990). After removal of AmpliWax, 0.6 vols 20\% PEG 8000 (Sigma) in $2.5 \mathrm{M} \mathrm{NaCl}$ were added and the mixture incubated at $37^{\circ} \mathrm{C}$ for $10 \mathrm{~min}$. The sample was centrifuged for $15 \mathrm{~min}$ at $15000 \mathrm{~g}$ and the pellet was washed with $80 \%$ ethanol and pelleted as before. The pellet was air-dried and dissolved in $30 \mu \mathrm{l}$ distilled water and used for cycle sequencing as described below.

Sequencing methods. The DNA sample from the PCR was directly sequenced using the TAQuence cycle-sequencing kit (US Biochemical). The manufacturer's protocol was followed. The eight sequencing primers used for Helicobacter 16S rRNA and for intervening sequences present at $E$. coli position 210 have been described previously (Fox et al., 1995). Primers were end-labelled with ${ }^{33} \mathrm{P}$ (NEN/Dupont) using the manufacturers' protocol. Approximately $100 \mathrm{ng}$ purified DNA from the PCR was used for sequencing. Reaction products were loaded on to $8 \%$ polyacrylamide/urea gels, electrophoresed and then detected by exposure to X-ray film for $24 \mathrm{~h}$. Some recent sequences were obtained using a model ABI 377 DNA sequencer with BigDye terminator cycle sequencing as described previously (Dewhirst et al., 1999).

16S rRNA data analysis. A program set for data entry, editing, sequence alignment, secondary-structure comparison, similarity-matrix generation and dendrogram construction for $16 \mathrm{~S}$ rRNA data was written in Microsoft Quick BASIC for use on PCs (Paster \& Dewhirst, 1988). RNA sequences were entered and aligned as described previously. Our sequence database contains approximately $1000 \mathrm{sequ}-$ ences determined in our laboratory and another 500 obtained from GenBank or the Ribosomal Database Project (Maidak et al., 1999). Similarity matrices were constructed from the aligned sequences by using only those sequence positions for which $90 \%$ of the strains had data. The similarity matrices were corrected for multiple base changes at single positions by the method of Jukes \& Cantor (1969). Phylogenetic trees were constructed using the neighbourjoining method of Saitou \& Nei (1987).

GenBank accession numbers. The GenBank and culture collection accession numbers for the strains examined in this study are given in Table 1 .

\section{RESULTS AND DISCUSSION}

Thirty-six strains of flexispira were examined by $16 \mathrm{~S}$ rRNA sequence analysis. The essentially complete (1450-1620 bases) sequence was determined for each strain. The GenBank and other accession numbers are given in Table 1 . Where multiple sequences differed by less than five bases, only one representative sequence was deposited with GenBank, but all of the sequences are available from the corresponding author. Comparison with sequences in our database indicated that all of the strains fell within the genus Helicobacter. The 36 strains fell into 10 distinct groups (some represented by only a single member), each of which probably represents a novel Helicobacter taxon (Table 1). The sequences of strains within each group differed by seven or fewer bases out of 1450 . A phylogenetic tree based on one strain from each group and 34 representative Campylobacter and Helicobacter species is shown in Fig. 1. This tree is based on an analysis of 1409 nucleotide positions. The flexispira taxa, while not monophyletic, do cluster in the helicobacter tree. They occur in the large central branch, away from the Helicobacter pylori-Helicobacter felis-'Gastrospirillum' branch, the Helicobacter pametensis-Helicobacter mustelae branch and the Helicobacter rodentium branch.

We have previously named two of the 10 taxa: Helicobacter bilis (flexispira taxon 9; Fox et al., 1995) and Helicobacter trogontum (flexispira taxon 6; Mendes et al., 1996). H. bilis, originally isolated from diseased livers of laboratory mice, has recently been isolated from dogs, hamsters, gerbils and rats, and the DNA of $H$. bilis has been detected in human bile and gall-bladder tissues in subjects with chronic cholecystitis (Eaton et al., 1996; Fox et al., 1998; Haines et al., 1998). This organism appears to have the broadest host range of any helicobacter described to date. Other than Helicobacter pylori, H. bilis may be the flexispira species with the greatest human pathogenic potential and therefore its role in hepatic disease is currently under intense scrutiny by several laboratories.

The flexispira taxon with the next highest number of isolates after $H$. bilis is flexispira taxon 8 . This group includes the original Archer human and dog isolates (Archer et al., 1988; Romero et al., 1988) as well as additional dog and mouse isolates. This taxon of isolates differs from other flexispira taxa (except flexispira taxon 7) in that most of the isolates are 


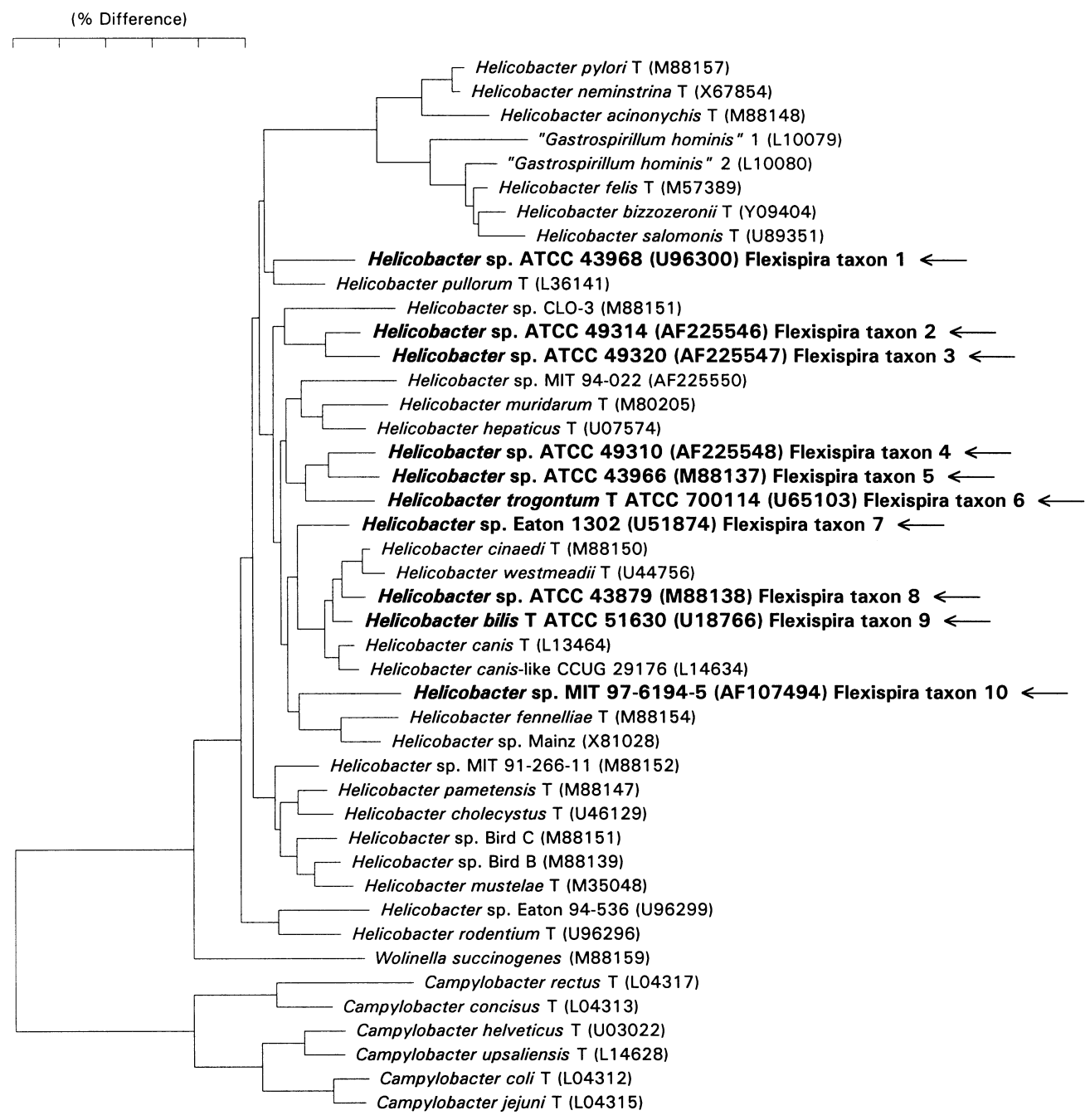

Fig. 1. Neighbour-joining phylogenetic tree for flexispira taxa and representative Helicobacter and Campylobacter species, based on 16S rRNA sequence comparisons of 1409 base positions. GenBank accession numbers are given in parentheses. Strains without culture collection numbers are type strains.

catalase-negative. Recently, three strains of flexispira taxon 8 have been recovered from patients with bacteraemia (Tee et al., 1998; Sorlin et al., 1999; Weir et al., 1999).

Flexispira taxon 2 includes six sheep isolates from aborted foetuses. Although strains of this taxon were isolated in South Dakota in the late 1980s, their worldwide role in association with animal diseases has not been examined.

Flexispira taxon 10 includes three isolates from cottontop tamarins (Saguinus oedipus). These helicobacter isolates have been described, but they have not been formally named because of the limited number of isolates obtained from a single colony of tamarins (Saunders et al., 1999). The tamarin colony has a high incidence of chronic colitis. The relationship between infection with this helicobacter and ulcerative colitis is under investigation.
The remaining flexispira taxa $(1,3,4,5$ and 7$)$ contain only one or two isolates per group. Strain ATCC 43966 is the sole representative of flexispira taxon 5, but it is the strain used to fulfil Koch's Postulates by producing abortions in sheep and guinea pigs (Kirkbride et al., 1985; Bryner et al., 1987). This particularly virulent strain caused placentitis and fetal hepatic necrosis. While abortions in domestic animals due to campylobacter infections have been well documented (Véron \& Chatelain, 1973), it is not clear whether earlier (and even subsequent) studies could clearly differentiate among the $>80$ taxa of Campylobacter, Arcobacter and Helicobacter that can now be differentiated by $16 \mathrm{~S}$ rRNA sequence analysis. Flexispira isolates have been recovered from aborted foetuses in sheep, pigs and dogs. The role of helicobacters in abortions in domestic animals needs to be examined. Even in sheep, it is not known whether transmission of helicobacters is faecal-oral or if helicobacters can 
Table 2. Characteristics that differentiate Helicobacter species

Data were obtained from Fox et al. (1994, 1995), Mendes et al. (1996), Saunders et al. (1999), Shen et al. (1997), On et al. (2000) and this study. +, 80-100\% strains positive; [+], 50-66\% strains positive; [-], 20-43\% strains positive;,$- 0-17 \%$ strains positive; s, susceptible; r, resistant; i, intermediate; W, weak; Nal, nalidixic acid (30 $\mu \mathrm{g}$ disk); Ceph, Cephalothin $(30 \mu \mathrm{g}$ disk)

\begin{tabular}{|c|c|c|c|c|c|c|c|c|c|c|c|c|c|c|}
\hline \multirow[t]{2}{*}{ Taxon } & \multirow{2}{*}{$\begin{array}{c}\text { Catalase } \\
\text { production }\end{array}$} & \multirow{2}{*}{$\begin{array}{c}\text { Nitrate } \\
\text { reduction }\end{array}$} & \multirow{2}{*}{$\begin{array}{c}\text { Alkaline } \\
\text { phosphatase } \\
\text { hydrolysis }\end{array}$} & \multirow[t]{2}{*}{ Urease } & \multirow{2}{*}{$\begin{array}{c}\text { Indoxyl } \\
\text { acetate } \\
\text { hydrolysis }\end{array}$} & \multirow{2}{*}{$\begin{array}{c}\gamma \text {-Glutamyl } \\
\text { transpeptidase }\end{array}$} & \multirow{2}{*}{$\begin{array}{l}\text { Growth } \\
\text { at } 42{ }^{\circ} \mathrm{C}\end{array}$} & \multirow{2}{*}{$\begin{array}{c}\text { Growth } \\
\text { with } 1 \% \\
\text { glycine }\end{array}$} & \multicolumn{2}{|c|}{ Susceptibility to: } & \multirow{2}{*}{$\begin{array}{c}\text { Periplasmic } \\
\text { fibres }\end{array}$} & \multirow{2}{*}{$\begin{array}{c}\text { No. } \\
\text { flagella }\end{array}$} & \multirow{2}{*}{$\begin{array}{c}\text { Distri- } \\
\text { bution of } \\
\text { flagella }\end{array}$} & \multirow{2}{*}{$\begin{array}{c}\mathrm{G}+\mathrm{C} \\
\text { content } \\
(\mathrm{mol} \%)\end{array}$} \\
\hline & & & & & & & & & Nal & Ceph & & & & \\
\hline H. pylori & + & - & + & + & - & + & {$[-]$} & - & $\mathrm{r}$ & s & - & $4-8$ & Bipolar & $35-37$ \\
\hline H. nemestrinae & + & - & + & + & - & & + & - & $\mathrm{r}$ & s & - & $4-8$ & Bipolar & 24 \\
\hline H. acinonychis & + & - & + & + & - & + & {$[-]$} & - & $\mathrm{r}$ & $\mathrm{s}$ & - & $2-5$ & Bipolar & 30 \\
\hline H. felis & + & + & {$[+]$} & + & {$[-]$} & + & {$[+]$} & - & $\mathrm{r}$ & s & + & $14-20$ & Bipolar & 42 \\
\hline H. bizzozeronii & + & + & {$[+]$} & + & {$[-]$} & + & {$[+]$} & & $\mathrm{r}$ & s & - & & Bipolar & \\
\hline H. salomonis & + & + & {$[+]$} & + & + & + & - & & $\mathrm{r}$ & s & - & & Bipolar & \\
\hline Flexispira taxon 1 & + & - & - & + & - & + & + & - & $\mathrm{r}$ & $\mathrm{r}$ & + & $10-20$ & Bipolar & \\
\hline H. pullorum & + & + & - & - & - & & + & - & $\mathrm{r}$ & s & - & 1 & Monopolar & $34-35$ \\
\hline Helicobacter sp. CLO-3 & + & - & + & - & + & - & + & + & $\mathrm{i}$ & $\mathrm{r}$ & - & & Bipolar & 45 \\
\hline Flexispira taxon 2 & + & - & - & + & - & + & + & - & $\mathrm{r}$ & $\mathrm{r}$ & + & & Bipolar & \\
\hline Flexispira taxon 3 & + & - & - & + & - & + & + & - & $\mathrm{r}$ & $\mathrm{r}$ & + & & Bipolar & \\
\hline H. muridarum & + & - & + & + & + & + & - & - & $\mathrm{r}$ & $\mathrm{r}$ & + & $10-14$ & Bipolar & 34 \\
\hline H. hepaticus & + & + & - & + & + & - & - & + & $\mathrm{r}$ & $\mathrm{r}$ & - & 2 & Bipolar & \\
\hline Flexispira taxon 4 & + & - & - & + & - & + & + & - & $\mathrm{r}$ & $\mathrm{r}$ & + & & Bipolar & \\
\hline Flexispira taxon 5 & + & - & - & + & - & + & + & W & $\mathrm{r}$ & $\mathrm{r}$ & + & & Bipolar & \\
\hline $\begin{array}{l}\text { Flexispira taxon } 6 \text { : } \\
\text { H. trogontum }\end{array}$ & + & + & - & + & - & + & + & & $\mathrm{r}$ & $\mathrm{r}$ & + & $5-7$ & Bipolar & \\
\hline Flexispira taxon 7 & - & - & - & + & - & + & $+/-$ & - & $\mathrm{r}$ & $\mathrm{r}$ & + & & Bipolar & \\
\hline H. cinaedi & + & + & {$[-]$} & - & - & - & {$[-]$} & + & s & $\mathrm{i}$ & - & $1-2$ & Bipolar & $37-38$ \\
\hline H. westmeadii & + & + & + & - & & & - & & s & $\mathrm{r}$ & & & Bipolar & \\
\hline Flexispira taxon 8 & - & - & - & + & - & + & + & - & $\mathrm{r}$ & $\mathrm{r}$ & + & $3-14$ & Bipolar & \\
\hline Flexispira taxon $9: H$. bilis & + & + & - & + & - & + & + & + & $\mathrm{r}$ & $\mathrm{r}$ & + & $3-14$ & Bipolar & \\
\hline H. canis & - & - & + & - & + & + & + & & s & $\mathrm{i}$ & - & 2 & Bipolar & 48 \\
\hline Flexispira taxon 10 & + & - & - & - & - & - & + & + & $\mathrm{r}$ & $\mathrm{r}$ & + & $6-12$ & Bipolar & \\
\hline H. fennelliae & + & - & {$[+]$} & - & + & - & {$[-]$} & + & s & s & - & 2 & Bipolar & 35 \\
\hline H. pametensis & + & + & + & - & - & - & + & {$[+]$} & $\mathrm{s}$ & s & - & 2 & Bipolar & 38 \\
\hline H. cholecystus & + & & + & - & - & - & + & + & $\mathrm{i}$ & $\mathrm{r}$ & - & & Bipolar & \\
\hline Helicobacter sp. Bird C & + & + & + & + & + & - & + & + & s & $\mathrm{r}$ & - & 2 & Bipolar & 30 \\
\hline Helicobacter sp. Bird B & + & + & + & + & - & + & + & + & $\mathrm{s}$ & $\mathrm{r}$ & - & 2 & Bipolar & 31 \\
\hline H. mustelae & + & + & + & + & {$[+]$} & + & + & - & $\mathrm{s}$ & $\mathrm{r}$ & - & $4-8$ & Peritrichous & 36 \\
\hline H. rodentium & + & + & - & - & - & - & + & + & $\mathrm{r}$ & $\mathrm{r}$ & - & 2 & Bipolar & \\
\hline
\end{tabular}

inhabit the male and female reproductive tracts and be transmitted sexually. Helicobacter hepaticus, isolated from diseased livers of mice (Fox et al., 1994), has been recovered from foetuses of near-term SCID mice, implying transplacental transmission (Li et al., 1998). Whilst the role of helicobacters in human abortions is probably minor in developed countries, it has never been examined. Indeed, helicobacters may play a significant role in some populations, particularly in developing countries in which people and animals share living spaces.

In sequencing the strains Bryner deposited in ATCC (provided to us by Phyllis Pienta of the American Type Culture Collection, ATCC), we noted a discrepancy between the sequence for strain ATCC 43966 and our previous sequence for strain NADC 1893 (supposedly the same strain). We received NADC 1893 from Bryner in 1991 and deposited its sequence in GenBank as M88137. The discrepancy was resolved by sequencing the original Kirkbride strain, 84-3345. Strain ATCC 43966 corresponds to the original Kirkbride strain and so GenBank entry M88137 (Eaton et al., 1993) has been corrected. Unfortunately, this strain sequencing error has misled other investigators into believing that the Kirkbride strain, ATCC 43966 (NADC 1893), is closely related to the Archer strain, ATCC 43879 (NADC 1937). In the recent study by Weir et al. (1999), based on the $99.8 \% 16 \mathrm{~S}$ rRNA sequence similarity between their 'Helicobacter rappinii' isolate and sequences M88137 (uncorrected) and M88138, they performed DNA-DNA hybridization but found only $24 \%$ DNA binding of their flexispira taxon 8 isolate to DNA from strain ATCC 43966 (a flexispira taxon 5 organism). Had the sequence M88137 for strain ATCC 43966 been correct at the time of their study, Weir et al. (1999) would have correctly chosen to use strain ATCC 43879 for their DNA-DNA hybridization studies and, as a result, would probably have demonstrated much higher binding.

The name 'F. rappini' was proposed in two abstracts from meetings (Bryner et al., 1986; Bryner, 1987), but the name was never approved. Now that it is know that flexispira belong to the genus Helicobacter, it is desirable to apply the combined name ' $H$. rappinii' to the appropriate flexispira taxon. Bryner proposed Kirkbride strain 84-3345 as the type strain for ' $F$. rappini'. It is not appropriate to name a species based upon a single isolate, but, unfortunately, strain 84- 
3345 is the only isolate representing the flexispira taxon 5 identified since 1984.

Flexispira taxon 8 could be a candidate for the name ' $H$. rappinii' because it includes the four original Archer strains plus several recent isolates. This taxon has the 16S rRNA sequence that has been associated with ' $F$. rappini' since 1993 (Eaton et al., 1993). What precludes us from naming flexispira taxon 8 ' $H$. rappinii' is that taxon 8 appears to be phenotypically heterogeneous. Half of the flexispira taxon 8 strains have an intervening sequence (IVS) of 187 bases replacing the 8-base helix that is normally present at position 198-219 (E. coli numbering). The Archer strains ATCC 43879, 43880, 49308 and 49309 and the recently reported human bacteraemia strains (Tee et al., 1998; Sorlin et al., 1999; Weir et al., 1999) do not have the IVS, whereas the remaining strains do. IVSs at this position have been found in several Campylobacter and Helicobacter species (Linton et al., 1994). The IVS, when present, is essentially identical to that found in $H$. bilis and differs by only approximately 6 bases from that found in flexispira taxon 2 strains. The Archer strains and a majority of remaining flexispira taxon 8 strains are catalase-negative. We have subsequently identified a helicobacter from mice (MIT 97-5078C; our unpublished results) that has essentially the same $16 \mathrm{~S}$ rRNA sequence as our taxon 8 isolates but lacks the flexispira morphology. The flexispira taxon 8 isolates may represent more than one species and therefore require further study before being named. Thus, we are currently in the unfortunate taxonomic position of being unable to name any of the eight unnamed flexispira taxa ' $H$. rappinii'. As shown in Table 2, several of the flexispira taxa cannot be distinguished by phenotypic criteria. We recommend that the name ' $H$. rappinii' (ra.pin'ni.i. N.L. gen. n. rappinii in honour of the 19th century microbiologist J. P. Rappin) be applied eventually to either flexispira taxon 5 or taxon 8 as these contain the initial isolates of Kirkbride and Archer, respectively. Until these remaining taxa are formally named, it may be useful to refer to these $16 \mathrm{~S}$ rRNA-sequence-defined taxa using the names given in Table 1, i.e. Helicobacter sp. flexispira taxon 1.

\section{ACKNOWLEDGEMENTS}

We thank Dr John Bryner, US Department of Agriculture, for initiating this work by sending two ' $F$. rappini' strains to F.E.D. and B.J.P. We thank Dr Irene Wesley for sending Dr Bryner's notes on ' $F$. rappini' strains after his retirement. We thank Phyllis Pienta of the ATCC for sending strains deposited by Bryner prior to general release of the strains. We thank Thomas MacAdoo (deceased), Virginia Polytechnic Institute and State University, for assistance in converting the name ' $F$. rappini' to ' $H$. rappinii'. This research was supported by grants DE 08303 and DE 11443 (to B.J.P.) and grant DE 10374 (to F.E.D.) from the National Institute for Dental and Craniofacial Research, and CA 26731 and CA 67529 from the National Cancer Institute, and DK 52413 from the National Institute of Diabetes and Digestive and Kidney Diseases (to J.G.F.).
E. N.M. was supported, in part, by a $\mathrm{CNPq} /$ Brazil Postdoctoral Fellowship while in the laboratory of J.G.F.

\section{REFERENCES}

Archer, J. R., Romero, S., Ritchie, A. E., Hamacher, M. E., Steiner, B. M., Bryner, J. H. \& Schell, R. F. (1988). Characterization of an unclassified microaerophilic bacterium associated with gastroenteritis, J Clin Microbiol 26, 101-105.

Bryner, J. H. (1987). Flexispira rappini, gen. nov., sp. nov. A motile, urease-producing rod similar to Campylobacter pyloridis. In Proceedings of the Fourth International Workshop on Campylobacter Infections, Göteborg, Sweden, pp. 440-442. Edited by Kaijer \& E. Falsen. Sweden: University Göteborg.

Bryner, J. H., Littleton, J., Gates, C., Kirkbride, C. A. \& Richie, A. E. (1986). Flexispira rappini gen. nov., sp. nov., a Gram-negative rod from mammalian fetus and feces. In XIV International Congress of Microbiology, Manchester, UK.

Bryner, J. H., Ritchie, A. E., Pollet, L., Kirkbride, C. A. \& Collins, J. E. (1987). Experimental infection and abortion of pregnant guinea pigs with a unique spirillum-like bacterium isolated from aborted ovine fetuses, Am J Vet Res 48, 91-95.

Dewhirst, F. E., Chien, C. C., Paster, B. J., Ericson, R. L., Orcutt, R. P., Schauer, D. B. \& Fox, J. G. (1999). Phylogeny of the defined murine microbiota: altered Schaedler flora, Appl Environ Microbiol 65, 3287-3292.

Eaton, K. A., Dewhirst, F. E., Radin, M. J., Fox, J. G., Paster, B. J., Krakowka, S. \& Morgan, D. R. (1993). Helicobacter acinonyx sp. nov., isolated from cheetahs with gastritis, Int $J$ Syst Bacteriol 43, 99-106.

Eaton, K. A., Dewhirst, F. E., Paster, B. J., Tzellas, N., Coleman, B. E., Paola, J. \& Sherding, R. (1996). Prevalence and varieties of Helicobacter species in dogs from random sources and pet dogs: animal and public health implications, J Clin Microbiol 34, 3165-3170.

Fox, J. G., Dewhirst, F. E., Tully, J. G., Paster, B. J., Yan, L., Taylor, N. S., Collins, M. J., Gorelick, P. L. \& Ward, J. M. (1994). Helicobacter hepaticus sp. nov., a microaerophilic bacterium isolated from livers and intestinal mucosal scrapings from mice, $J$ Clin Microbiol 32, 1238-1245.

Fox, J. G., Yan, L., Dewhirst, F. E., Paster, B. J., Shames, B., Murphy, J. C., Hayward, A., Belcher, J. C. \& Mendes, E. N. (1995). Helicobacter bilis sp. nov., a novel Helicobacter isolated from bile, livers, and intestines of aged, inbred mouse strains, J Clin Microbiol 33, 445-454.

Fox, J. G., Dewhirst, F. E., Shen, Z. \& 8 other authors. (1998). Hepatic Helicobacter species identified in bile and gallbladder tissue from Chileans with chronic cholecystitis. Gastroenterology 114, 1-10.

Haines, D. C., Gorelick, P. L., Battles, J. K. \& 8 other authors. (1998). Inflammatory large bowel disease in immunodeficient rats naturally and experimentally infected with Helicobacter bilis. Vet Pathol 35, 202-208.

Jukes, T. H. \& Cantor, C. R. (1969). Evolution of protein molecules. In Mammalian Protein Metabolism, vol. 3, pp. 21-132. Edited by H. N. Munro. New York: Academic Press.

Kirkbride, C. A., Gates, C. E., Collins, J. E. \& Ritchie, M. S. (1985). Ovine abortion associated with an anaerobic bacterium, $J \mathrm{Am}$ Vet Med Assoc 186, 789-791.

Kirkbride, C. A., Gates, C. E. \& Collins, J. E. (1986). Abortion in sheep caused by a non-classified, anaerobic, flagellated bacterium, Am J Vet Res 47, 259-262.

Kusukawa, N., Uemori, T., Asada, K. \& Kato, I. (1990). Rapid and 
reliable protocol for direct sequencing of material amplified by the polymerase chain reaction, Biotechniques 9, 66-72.

Li, X., Fox, J. G., Whary, M. T., Yan, L., Shames, B. \& Zhao, Z. (1998). SCID/NCr mice naturally infected with Helicobacter hepaticus develop progressive hepatitis, proliferative typhlitis, and colitis, Infect Immun 66, 5477-5484.

Linton, D., Dewhirst, F. E., Clewley, J. P., Owen, R. J., Burnens, A. P. \& Stanley, J. (1994). Two types of $16 \mathrm{~S}$ rRNA gene are found in Campylobacter helveticus: analysis, applications and characterization of the intervening sequence found in some strains, Microbiology 140, 847-855.

Lockard, V. G. \& Boler, R. K. (1970). Ultrastructure of a spiraled microorganism in the gastric mucosa of dogs, Am J Vet Res 31, 1453-1462.

Maidak, B. L., Cole, J. R., Parker, C. T., Jr. \& 11 other authors (1999). A new version of the RDP (Ribosomal Database Project). Nucleic Acids Res 27, 171-173.

Mendes, E. N., Queiroz, D. M. M., Dewhirst, F. E., Paster, B. J., Moura, S. B. \& Fox, J. G. (1996). Helicobacter trogontum sp. nov., isolated from the rat intestine, Int J Syst Bacteriol 46, 916-921.

On, S. L. W., Lee, A., O'Rourke, J. O., Dewhirst, F. E., Paster, B. J., Fox, J. G. \& Vandamme, P. (2000). Genus Helicobacter Goodwin, Armstrong, Chilvers, Peters, Collins, Sly, McConnell, Harper $397^{\mathrm{VP}}$. In Bergey's Manual of Systematic Bacteriology, 2nd edn, vol. 2 (in press). New York: Springer.

Paster, B. J. \& Dewhirst, F. E. (1988). Phylogeny of campylobacters, wolinellas, Bacteroides gracilis, and Bacteroides ureolyticus by $16 \mathrm{~S}$ ribosomal ribonucleic acid sequencing, Int J Syst Bacteriol 38, 56-62.

Paster, B. J., Lee, A., Fox, J. G., Dewhirst, F. E., Tordoff, L. A., Fraser, G. J, O'Rourke, J. L., Taylor, N. S. \& Ferrero, R. (1991). Phylogeny of Helicobacter felis sp. nov., Helicobacter mustelae, and related bacteria, Int $J$ Syst Bacteriol 41, 31-38.

Romero, S., Archer, J. R., Hamacher, M. E., Bologna, S. M. \& Schell, R. F. (1988). Case report of an unclassified microaerophilic bacterium associated with gastroenteritis, $J$ Clin Microbiol 26, 142-143.
Saitou, N. \& Nei, M. (1987). The neighbor-joining method: a new method for reconstructing phylogenetic trees, Mol Biol Evol 4, 406-425.

Saunders, K. E., Shen, Z., Dewhirst, F. E., Paster, B. J., Dangler, C. A. \& Fox, J. G. (1999). Novel intestinal Helicobacter species isolated from the cotton-top tamarins (Saguinus oedipus) with chronic colitis, J Clin Microbiol 37, 146-151.

Savage, D. C., McAllister, J. S. \& Davis, C. P. (1971). Anaerobic bacteria on the mucosal epithelium of the murine large bowel, Infect Immun 4, 492-502.

Schauer, D. B., Ghori, N. \& Falkow, S. (1993). Isolation of 'Flexispira rappini' from mice, J Clin Microbiol 31, 2709-2714.

Shen, Z., Fox, J. G., Dewhirst, F. E., Paster, B. J., Foltz, C. J., Yan, L., Shames, B. \& Perry, L. (1997). Helicobacter rodentium sp. nov., a urease-negative Helicobacter species isolated from laboratory mice, Int J Syst Bacteriol 47, 627-634.

Sorlin, P., Vandamme, P., Nortier, J., Hoste, B., Rossl, C., Pavlof, S. \& Struelens, M. J. (1999). Recurrent 'Flexispira rappini' bacteremia in an adult patient undergoing hemodialysis: case report, J Clin Microbiol 37, 1319-1323.

Tee, W., Leder, K., Karroum, E. \& Dyall-Smith, M. (1998). 'Flexispira rappini' bacteremia in a child with pneumonia, $J$ Clin Microbiol 36, 1679-1682.

Vandamme, P., Falsen, E., Rossau, R., Hoste, B., Segers, P., Tytgat, R. \& De Ley, J. (1991). Revision of Campylobacter, Helicobacter, and Wolinella taxonomy: emendation of generic description and proposal of Arcobacter gen. nov, Int J Syst Bacteriol 41, 88-103.

Véron, M. \& Chatelain, R. (1973). Taxonomic study of the genus Campylobacter Sebald and Véron and designation of the neotype strain for the type species, Campylobacter fetus (Smith and Taylor) Sebald and Véron, Int J Syst Bacteriol 23, 122-134.

Weir, S., Cuccherini, B., Whitney, A. M. \& 9 other authors. (1999). Recurrent bacteremia caused by a 'Flexispira'-like organism in a patient with X-linked (Bruton's) agammaglobulinemia. J Clin Microbiol 37, 2439-2445. 